MARTA KRASUSKA-BETIUK

Wydział Nauk Pedagogicznych

Akademia Pedagogiki Specjalnej

im. M. Grzegorzewskiej w Warszawie

ORCID ID: http://orcid.org/oooo-ooo2-8743-1481
Forum Pedagogiczne $2018 / 2$

Wpłynęło: 21.04.2018

Zatwierdzono do druku: 26.09.2018 DOI: 10.21697/fp.2018.2.06

\title{
SZKOLNA NAUKA CZYTANIA I PISANIA Z WYKORZYSTANIEM WYBRANYCH ELEMENTARZY - REFLEKSJE METODYCZNE
}

\begin{abstract}
Streszczenie: Tekst dotyczy nauki czytania i pisania na początkowym etapie nauczania szkolnego oraz roli elementarzy w procesie alfabetyzacji dziecka. Artykuł ma charakter przeglądowy. W części pierwszej wskazano psycholingwistyczne podstawy czytania i pisania oraz różnice między systemami językowymi, warunkujące zastosowanie określonych metod nauki czytania i pisania. Opisano strukturę, funkcję i metodyczne aspekty pracy z elementarzem, który potraktowany został jako efektywna pomoc dydaktyczna i skuteczna forma inicjacji dziecka w świat pisma. W części drugiej scharakteryzowano wybrane elementarze oraz proponowane przez ich autorów koncepcje nauki czytania i pisania. Do analizy elementarzy zastosowano podejście tradycyjne - dydaktyczne i nieoceniające. $\mathrm{Na}$ koniec wskazano przykłady współczesnych elementarzy polskich, niemieckich i jeden rosyjski. Kryterium ich doboru był długoletni okres wykorzystywania (blisko pół wieku) w pierwszych latach nauki szkolnej oraz dominacja metod analityczno-syntetycznych w nauczaniu czytania i pisania.
\end{abstract}

Słowa kluczowe: wczesna alfabetyzacja, czytanie i pisanie, współczesne elementarze.

\section{Wprowadzenie}

$\mathrm{Na}$ świecie i w Polsce badania w polu literacy prowadzone są w ramach różnych dyscyplin naukowych. Eksperci UNESCO w ostatnio wydanych raportach Education for All. Literacy for life. Global Monitoring Reports (2005) i Reading the past, writing the future: Fifty years of promoting literacy (2017) - przyjęli szerokie rozumienie umiejętności czytania i pisania, obejmujące: zdolność rozpoznawania, rozumienia, interpretowania, tworzenia, komunikowania się i liczenia, przy użyciu materiałów drukowanych i pisemnych, związanych z różnymi kontekstami i mediami. Umiejętność czytania i pisania stanowi centralny element badań nad mother 
tongue, gdzie elary literacy analizuje się w aspekcie porównawczym i w kontekście interkulturowym ${ }^{1}$.

W polskim piśmiennictwie gotowość do czytania w aspekcie rozwoju metajęzykowego prześledziła Grażyna Krasowicz-Kupis (1999). Krystyna Sochacka z kolei (2004) przedstawiła szczegółowy przegląd rozwojowych modeli czytania i wyniki badań własnych nad strategiami czytania stosowanymi przez dzieci w początkowym okresie nauki. Lingwistyczne podstawy początkowej nauki czytania i pisania wnikliwie opisała Elżbieta Awramiuk (2006). Kompleksowe opracowanie empiryczne dotyczące metod czytania i pisania w przedszkolu i osiągnięć sześciolatków w tym zakresie wyszło spod pióra Elżbiety Jaszczyszyn (2010). Cenne są w tym zakresie także wyniki badań dotyczących związków między elementarzową nauką czytania i pisania a osiągnięciami uczniów Anny Jurek (2012). Na początku opracowania zostaną przedstawione najistotniejsze lingwistyczne determinanty procesu nabywania umiejętności czytania i pisania. W drugiej części tekstu zaprezentowano wybrane elementarze krajowe i stosowane przez naszych najbliższych sąsiadów. Pierwsza książka, podręcznik do nauki czytania i pisania dla dzieci w wieku wczesnoszkolnym, ogniskuje i w dużym stopniu wyznacza tok pracy dydaktycznej, szczególnie w pierwszych latach instytucjonalnej nauki czytania, która w różnych krajach rozpoczyna się w różnym wieku. W refleksji nad podręcznikami widoczne są dwa podejścia. Pierwsze, typowe dla bardziej tradycyjnych podejść, skupia się na nieoceniającym wskazywaniu roli, funkcji i cech „typowego” (egzemplarycznego) podręcznika; drugie - na ich krytycznej analizie, jako tekstu kulturowego, dokonywanej z różnych perspektyw teoretycznych i normatywnych (Kostouli 2002; Uszyńska-Jarmoc, Żak 2013; Klus-Stańska 2014; Tainio, Winkler 2014).

\section{Modele opanowywania umiejętności czytania}

Teorie wyjaśniające proces nabywania umiejętności czytania konstruowano na bazie odkryć psychologii poznawczej i lingwistyki. W efekcie powstały rozwojowe modele czytania, przedstawiające ten złożony proces w postaci sekwencyjnie następujących po sobie stadiów oraz modele konekcjonistyczne, odnoszące się do systemu przetwarzania informacji przez umysł ludzki (Sochacka 2004, s. 83). Kierunek rozwoju zdolności fonologicznych ma charakter uniwersalny w ramach różnych języków europejskich, a przebieg procesu przyswajania dekodowania jest podobny. W większości znanych koncepcji dominuje pogląd, iż opanowywanie

1 Badania te rozwijają się niezwykle intensywnie od lat, nieocenionym źródłem wiedzy, raportów badawczych są centra badawcze i stowarzyszenia, wśród nich zawiązane w 1994 roku International Association for the Improvement of Mother Tongue Education (IAIMTE), którego celem jest inicjowanie międzynarodowej współpracy specjalistów w dziedzinie uczenia się i nauczania języka ojczystego i upowszechnianie wyników badań na łamach m.in. czasopisma L1 Educational Studies in Language and Literature. 
czytania przechodzi przez fazę wzrokową (rozpoznawanie wzrokowe elementów tekstu) do językowej, w której odkrywany jest związek fonem-grafem (głoska-litera). Warto krótko wspomnieć o najbardziej znanych modelach.

I tak oto G. Marsh, M. Freidman, U. Welch i P. Desbergo (1983) opisali przebieg nabywania umiejętności czytania w języku angielskim (Sochacka 2004). W trakcie dwóch pierwszych stadiów dzieci korzystają ze strategii leksykalnych (całościowych) opartych na pamięciowym uczeniu się przy użyciu bezpośredniej drogi wzrokowej. W dwóch następnych etapach posługują się strategiami subleksykalnymi (analitycznymi), poprzez dźwięk docierają do znaczenia wyrazów, dokonując zamiany liter na głoski, a następnie syntezy głosek w formę wyrazu. Etapy te wymagają opanowania sprawności fonologicznych.

Uta Frith (1985) opracowała uniwersalny trójfazowy model rozwoju umiejętności czytania dzieci w wieku od sześciu do dziewięciu lat, który uznawany był za charakterystyczny dla przebiegu rozwoju czytania w różnych systemach językowych, i jako taki przyjmowany jest za obowiązujący również w innych krajach. Badaczka dowiodła, że dziecko w opanowaniu umiejętności czytania i pisania przechodzi kolejno przez fazę logograficzną (wyrazy - logogramy są rozpoznawane wzrokowo jako całość na podstawie ich wyglądu, bez zwracania uwagi na poszczególne litery), alfabetyczną (dziecko ma świadomość podziału słowa na fonemy) i ortograficzną (sprawne dekodowanie brzmieniowe fonemów). W każdej z tych faz można wyróżnić kolejne kroki. Powszechnie przyjęty na świecie model Uty Frith w przypadku dzieci polskich nie przebiega przez fazę logograficzną. Czytanie nie ma też charakteru wzrokowego, a najsilniejszymi predykatorami czytania są umiejętności o charakterze metajęzykowym, zwłaszcza umiejętność operowania cząstkami fonologicznymi.

Znany jest model opanowywania czytania według Johna L. Kirby’ego (1990), który w rozwoju sprawności czytania wyróżnia trzy fazy: globalną - poprzedzającą właściwe czytanie, gdy czytający rozpatruje tekst jako całość i nie rozpoznaje nieznanych słów; analityczną - w tej fazie dziecko „łamie kod”, czyli zaczyna dzielić wyrazy na części składowe, wiążąc dźwięki z symbolami wizualnymi; syntetyczną, reprezentująca sprawne czytanie, w którym czytający łączy ukierunkowanie na treść z analityczną zdolnością do szybkiego i precyzyjnego rozpoznawania wyrazu (Krasowicz-Kupis 1999, s. 10).

Neuropsychologiczna koncepcja zmiennego zaangażowania półkul mózgowych w procesie opanowywania czytania D. Bakkera $(1990,1998)$ wiąże proces nauki czytania z lateralizacją funkcji poznawczych. Problemem przyczynowości w nauce czytania zajmowali się P. Bryant i U. Goswami (1990). Zaproponowali przyczynową teorię czytania, koncentrując się na określaniu czynników warunkujących postęp w nauce czytania (Sochacka 2004, s. 97). Podstawę umiejętności czytania i pisania stanowi świadomość struktur językowych. Rozwój świadomości językowej postępuje w kierunku od zdolności wyodrębniania jednostek większych ku coraz mniejszym, a więc najwcześniej dzieci potrafią wyodrębniać wyrazy, następnie 
aliteracje i rymy, a na końcu, już jako efekt nauczania, poszczególne fonemy. Autorzy sugerowali, że taki kierunek rozwoju może być uniwersalny dla różnych języków. Pośród modeli konekcjonistycznych na uwagę zasługuje model podwójnej podstawy według P. Seymoura (1999), uwzględniający procesy poznawcze zaangażowane we wczesnym okresie nauki czytania. Koncepcja ta łączy w sobie opisywane wcześniej modele (poznawcze, rozwojowe, przyczynowe, stadialne)².

\section{Przygotowanie do czytania i pisania}

Okres przygotowawczy zaczyna się na długo przed rozpoczęciem formalnej nauki czytania i pisania. To czas wyrabiania gotowości do nauki tych umiejętności, co jest przedmiotem oddzielnych badań empirycznych i rozwiązań praktycznych. W nurcie badań psychologicznych wskazuje się na wielofunkcyjność właściwości czytania. Zdaniem Eve Malmquist, „psychologiczny proces czytania obejmuje wszystko, co dzieje się od chwili, gdy zaczynamy reagować na bodźce wizualne, wywoływane napisanymi lub wydrukowanymi wyrazami, aż do produktu czytania [...] - odpowiedzi czytającego na te bodźce w postaci myśli, reakcji uczniów, mówionych lub napisanych słów" (Malmquist 1982, s. 19). Anna Brzezińska zdefiniowała gotowość do nauki czytania i pisania jako „stan w rozwoju dziecka będący rezultatem dojrzewania oraz dotychczasowego treningu wychowawczego przede wszystkim na terenie rodziny, który czyni je wrażliwym na znaki, ich istotę i znaczenie w procesie komunikowania się ludzi, a jednocześnie gotowym do odnoszenia korzyści ze wskazówek otoczenia dotyczących opanowania umiejętności czytania i pisania" (Brzezińska 1987, s. 43-44).

Złożoność procesów czytania i pisania każe uznać iż, stanowią je: 1. czynność językowa (formę komunikacji opartą na języku); 2. czynność metajęzykowa, oparta na: świadomości pisma, głównie relacji druk-słowo, świadomości relacji głoska-litera, świadomości środków językowych użytych do formowania wypowiedzi i ich kontroli; 3. czynność metapoznawcza, wymagająca świadomej kontroli procesów poznawczych zaangażowanych w czytanie, a dokładniej rozumienia tekstu; 4. czynność pragmatyczna i metapragmatyczna, wymagająca umiejętności celowego posługiwania się tekstami pisanymi i kontroli ich zastosowań z punktu widzenia celów osobistych i ponadindywidualnych. W celu stworzenia podstaw nauki czytania rozwija się początkową umiejętność czytania u dzieci poprzez różne działania, które $\mathrm{w}$ istocie nie wymagają faktycznego dekodowania tekstów pisanych. Elementem tych przygotowań jest zwiększenie świadomości fonologicznej (umiejętności dzielenia języka mówionego na jednostki dźwiękowe - sylaby i fonemy). Inny ważny

2 Modele czytania z podziałem na stadia spotykają się często z krytyką, gdyż indywidualne różnice sprawiają, że każde dziecko dobiera sobie strategię bardziej odpowiednią ze względu na styl przetwarzania informacji (bardziej syntetyczny lub analityczny) i przyswaja własny, odrębny od innych styl czytania w odpowiednim dla siebie tempie. 
komponent wczesnej umiejętności czytania to rozwój koncepcji i wiedzy dzieci na temat druku (kodu graficznego), co ma pomagać w konceptualizowaniu przez nie pisania jako reprezentacji języka mówionego. W kształtowaniu świadomości pisma pomocne są atrakcyjne materiały wizualne prezentujące różne alfabety, także najstarszy (fenicki), na podstawie którego ukształtowały się alfabet grecki i łaciński, i które dały początek pozostałym alfabetom europejskim. Dodatkowo warto zapoznać dzieci z historią pisma, pokazać odmienne rodzaje pisma (piktograficzne, klinowe, fonograficzne, runiczne), egipskie hieroglify i alfabety specjalne.

Stworzenie mocnych podstaw dla nauki czytania we wczesnej fazie powoduje, że ogólnokrajowe programy nauczania dla edukacji przedszkolnej we wszystkich państwach zawierają wskazówki dotyczące rozwijania kształtującej się dopiero umiejętności czytania. Raport EURYDICE Teaching Reading in Europe: Contexts, Policies and Practices z 2011 roku przedstawia podstawowe czynniki wpływające na nabywanie umiejętności czytania oraz krajowe strategie związane z tymi czynnikami. Umiejętność czytania jest w nim określana jako pełna zdolność do rozumienia, używania i przeprowadzenia refleksji nad formami języka pisanego, umożliwiająca osiągnięcie osobistego i społecznego spełnienia. Wykracza ona poza kognitywne komponenty czytania (tzn. odkodowywania słów i rozumienia tekstu), kierując się na inne aspekty związane z motywacją i zaangażowaniem w obcowanie $\mathrm{z}$ materiałami pisanymi. W kontekście szkolnym - uczniowie powinni doskonale opanować umiejętność czytania, nauczyć się czytać i biegle „czytać, by się uczyć”.

Dla prowadzonych w niniejszym tekście rozważań istotne są wnioski z badania fazy początkowej procesu nauki czytania i pisania. Świadomość fonologiczna (umiejętność wychwytywania i używania segmentów dźwiękowych składających się na słowa mówione) i świadomość fonemiczna (rozumienie fonemów), fonika (zależność grafemiczno-fonemiczna, sposób powiązania liter z dźwiękiem) i płynność (automatyzm rozpoznawania słów, umiejętność czytania fragmentów tekstu w sposób dokładny, szybki, bez wysiłku i z odpowiednią ekspresją/prozodią) w czytaniu mają największe znaczenie we wczesnych fazach rozwoju tej umiejętności. System ortograficzny ma istotny wpływ na kształtowanie się świadomości podstawowych jednostek języka.

Najistotniejsza dla nauki czytania i pisania jest relacja między mową a pismem, czyli relacja między fonemem a grafemem. Języki naturalne różnią się na każdym poziomie systemowym (fonologicznym, morfologicznym, składniowym i leksykalnym). Relacja fonem-graf (F-G) jest istotna dla pisania, zaś graf-fonem (G-F) dla czytania. W wielu językach (fiński, turecki, serbsko-chorwacki) wiedza o tym, jak dany wyraz należy wymówić, jest jednocześnie informacją o tym, jak dany wyraz zapisać (Awramiuk 2006). Zależność grafemiczno-fonemiczna może być jednym $\mathrm{z}$ ważniejszych zagadnień $\mathrm{w}$ nauce czytania w niektórych państwach w porównaniu $\mathrm{z}$ innymi, ponieważ wysiłek konieczny do nauczenia się czytania różni się w zależności od języka (Delhaxhe i in. 2011). 


\section{Czytanie i pisanie w różnych systemach językowych i ortograficznych}

$\mathrm{Na}$ opanowanie literacy mają wpływ m.in.: liczba fonemów, proporcje między fonemami spółgłoskowymi i samogłoskowymi, zasady łączenia fonemów, fonologiczne cechy dystynktywne, struktura sylaby i akcent wyrazowy. Szczegółowa charakterystyka każdego komponentu przekracza ramy niniejszego tekstu. Warto jednak uwypuklić czynniki decydujące o nauce czytania i pisania, determinują one bowiem strukturę gramatycznej części elementarzy.

Różnice w systemach ortograficznych (writting systems) mają wpływ na łatwość bądź trudność opanowania czytania i pisania. Dotyczą one takich aspektów, jak przejrzystość (transparency) ${ }^{3}$, regularność (regularity) i spójność (consistency). W literaturze pojawia się także podział ortografii na płytkie (shallow orthography) i głębokie (deep orthography). W językach o spójnej ortografii taka sama litera zawsze jest wymawiana w ten sam sposób w różnych słowach, a w językach o ortografii niespójnej relacje między literą a dźwiękiem mogą być zmienne ${ }^{4}$. Ma to znaczące konsekwencje w rozwoju umiejętności czytania, a co za tym idzie - w zaleceniach dotyczących nauki czytania w Europie i proponowanych nauczycielom pomocom dydaktycznym, w tym podręcznikom.

Philip H. K. Seymour, Mikko Aro, Jane M. Erskinez (2003) badali wczesną (tzw. podstawową) fazę nabywania umiejętności czytania w języku angielskim i 12 innych językach (ortografiach) europejskich. Otrzymane wyniki świadczą o tym, że uczniowie w większości państw europejskich nabywają precyzję i płynność na poziomie podstawowym przed ukończeniem pierwszej klasy szkoły podstawowej. Wyjątki od tej zasady dotyczą zwłaszcza języka francuskiego, portugalskiego, duńskiego, i szczególnie angielskiego. Wynika to z podstawowych różnic językowych w zakresie złożoności sylabicznej i spójności ortograficznej. Rozwój podstawowych umiejętności czytania w językach o niespójnej ortografii zajmuje ponad dwa razy więcej czasu niż w przypadku języków o ortografii spójnej.

Model nabywania umiejętności czytania przez dzieci polskie opracowała Grażyna Krasowicz-Kupis (2008), zaś model komunikacji pisemnej w języku polskim opracowały Elżbieta Awramiuk i Grażyna Krasowicz-Kupis (2014). Zgodnie z tym ostatnim modelem opanowywanie umiejętności komunikowania się za pomocą pisma przechodzi przez trzy główne stadia: wstępne - przed nauką pisma, kluczowe - związane z opanowaniem pisma, oraz wprawy - odnoszące się do

3 Im większa różnica między liczbą grafemów i fonemów, tym dalej od przejrzystości. Nieprzejrzyste są np. ortografia angielska i ortografia francuska. Analizy grafemicznej nie wymaga język serbsko-chorwacki zapisany cyrylicą, gdyż wszystkie fonemy mają pojedyncze oznaczenia literowe (cyt. za: Awramiuk 2006, s. 61).

4 Na przykład ortografia i sylabiczna struktura języków: angielskiego, francuskiego, duńskiego i portugalskiego jest zasadniczo inna oraz bardziej złożona od struktury innych języków europejskich o bardziej spójnej ortografii, jak język fiński, grecki, włoski i hiszpański. 
automatyzacji posługiwania się pismem. Stadium kluczowe ma swoją specyfikę w odniesieniu do czytania i nieco inną w odniesieniu do pisania. W czytaniu przebiega ono przez trzy etapy: 1) etap fonologiczny (początkowe miesiące nauki), w którym występuje wyraźna dominacja strategii opartej na przetwarzaniu fonologicznym wykorzystującym relację litera-głoska; 2) etap pośredni między czytaniem fonologicznym a globalnym wyrazowym (po ok. roku nauki), w którym nadal dominuje strategia analityczna, jednak oparta na cząstkach większych od pojedynczych fonemów; 3) etap czytania globalnego (dominacja strategii całościowych wyrazowych i frazowych), w którym zaczyna dominować strategia całościowa, wyrazowa lub frazowa. W pisaniu polskie językoznawczynie (Wiejak i in. 2017) wyróżniły trzy fazy, jakkolwiek granice między nimi są raczej płynne, a czas występowania - bardziej zindywidualizowany. Są to etapy: częściowej i pełnej reprezentacji fonetycznej oraz reprezentacji ortograficznej. Proponowany wspólny model przyswajania czytania i pisania pokazuje, że w istocie proces ten jest przyswajaniem językowej komunikacji za pośrednictwem pisma. Czas osiągnięcia stadium wprawy w wypadku czytania i pisania może być nieco inny, tzn. dziecko może osiągnąć stadium wprawy w czytaniu, ale jeszcze pozostawać w stadium poprzednim w zakresie pisania. Różnice między obiema umiejętnościami dotyczą stadium kluczowego i wynikają z odmiennego kierunku przepływu informacji od wersji graficznej do fonetycznej i odwrotnie, a co za tym idzie - nieco odmiennych procesów poznawczych i językowych zaangażowanych w odczytywanie tekstu i jego zapisywanie (Wiejak i in. 2017, s. 45).

\section{Struktura i funkcje podręczników do nauki czytania i pisania}

Elementarius - w języku łacińskim oznacza początkowy. Podręcznik o tej nazwie ma szczególne znaczenie w pierwszych latach edukacji, stanowi pomoc dydaktyczną dla dzieci o charakterze inicjacyjnym, instrument alfabetyzacji, jest też środkiem dydaktycznym ułatwiającym opanowanie czytania i pisania - narzędzi kulturowych i zarazem kluczowych kompetencji umożliwiających uczenie się. W niniejszym opracowaniu przyjęto opisowy model analizy elementarzy, w którym traktowane są one jako narzędzia wykorzystywane w procesie dydaktycznym. Takie ujęcie zakłada, że do każdego podręcznika przypisani są dwaj adresaci: 1) nauczyciel, dla którego podręcznik stanowi istotną pomoc naukową, jest zapisem pewnej koncepcji metodycznej; 2) uczeń, wobec którego podręcznik powinien spełniać szereg funkcji dydaktycznych: informacyjną, motywacyjną, transformacyjną, samokształceniową, kontrolno-oceniającą, które „realizują się” za pośrednictwem języka (Krzyżyk 2015). Twórca podręcznika do nauczania języka ojczystego odwołuje się do obowiązujących w danym czasie teorii nauczania, metod i celów edukacji językowej i literackiej. Nie bez znaczenia jest także kontekst lokalny dyskursu edukacyjnego, związany z konkretną sytuacją komunikacyjno-dydaktyczną, miejscem, warunkami zewnętrznymi. 
W analizie elementarzy stosowane są najczęściej następujące kryteria: podejście do procesu czytania (np. techniczne, psycholingwistyczne), metody nauki czytania (syntetyczne, analityczne, globalne, analityczno-syntetyczne, mieszane i eksperymentalne), kolejność wprowadzania liter, dobór treści, warstwa językowa, obudowa metodyczna (pomoce dydaktyczne takie jak: karty pracy, plansze i tablice demonstrujące litery alfabetu), dobór ilustracji, tekstów kultury i ćwiczeń rozwijających sprawności językowe (Cackowska 1984). Stałym elementem wielu elementarzy są postacie bohaterów prowadzących. Jest to najczęściej para dziewczynka i chłopiec - rówieśnicy odbiorców elementarza. Pełnią oni funkcję narratorów wprowadzających pierwszoklasistów - czytelników w świat elementarza i tajniki nauki, są bohaterami pierwszych czytanek dla dzieci na całym świecie (Szefler 2017).

W Polsce z każdym elementarzem związana jest (a przynajmniej powinna być) mniej lub bardziej klarowna koncepcja pedagogiczno-metodyczna, opracowana zgodnie z najnowszymi teoriami naukowymi z obszaru early literacy. Nauka elementarzowa odbywa się w naszym kraju zgodnie $\mathrm{z}$ metodą analityczno-syntetyczną o odmianie wyrazowej (Awramiuk 2006; Czelakowska 2013). Jest to metoda odpowiadająca właściwościom polskich systemów językowego i ortograficznego. Podstawą analizy (wzrokowej lub słuchowej), a następnie syntezy jest wyraz zawierający poznawaną literę lub głoskę. Niektóre koncepcje akcentują przydatność sylaby i wyodrębnianie większych niż litera cząstek wyrazów, np. deklinacyjnych, słowotwórczych. Na początku nauki szkolnej uczniowie poznają podstawowe litery alfabetu (a jeśli je już poznały w przedszkolu uczą się pisania). Kolejność poznawania poszczególnych liter uzależniona jest od koncepcji dydaktycznej (tzw. obudowy metodycznej) pierwszej książki ucznia. Zmianę pierwotnej funkcji elementarza (jaką było zapewnienia dziecku pierwszego kontaktu z pismem) widać na przykładzie kolejności wprowadzanych liter (Awramiuk 2006, s. 125). W czasach gdy elementarz był w Polsce pierwszą książką szkolną, najpierw wprowadzano takie litery (M, A, K, O, T, D, U), które pozwalały kodować polskie wyrazy typu mama, tata, dom i układać proste zdania: Ala ma kota ${ }^{5}$. Następnie zazwyczaj wprowadzano zmiękczenia przez „i” oraz znak diakrytyczny, na końcu dwuznaki. Obecnie kolejność liter w elementarzu nie jest już tak istotna. Wiadomo natomiast, że naukę czytania najlepiej prowadzić równolegle z nauką pisania, gdyż umiejętności te są ściśle ze sobą powiązane. Wszystkie działania związane z nauką czytania i pisania warto podporządkować podejściom polisensorycznym.

5 Powiedzenie „Ala ma kota” weszło do języka potocznego jako symbol Elementarza Mariana Falskiego. Językoznawca Jerzy Bralczyk zwraca jednak uwagę, że próżno szukać tego sformułowania w elementarzu, który zaczyna się od zdania „To As” i potem następuje „As to pies Ali”. Kot pojawia się dopiero na kolejnych stronach, konkretnego zdania - „Ala ma kota” - w książce po prostu nie ma. 


\section{Kwestia doboru metod czytania i pisania w elementarzach}

W doborze metod nauczania czytania i pisania pierwszorzędną rolę odgrywają uwarunkowania językowe danego systemu - fonetyczne, morfologiczne i ortograficzne. Istotą dobrego elementarza jest zatem zgodność postulowanych metod Z właściwościami danego systemu językowego i systemu ortograficznego. Systemy pisma - ideograficzne, sylabiczne, alfabetyczne, mieszane reprezentują język mówiony w odmienny sposób i stawiają przed uczącymi się różne wymagania (Coulmas 1999). W każdym języku mówionym występują głoski, sylaby i wyrazy, ale każdy system pisma uprzywilejowuje jedna $\mathrm{z}$ tych jednostek, przyjmując ją za podstawę (Awramiuk 2006, s. 78). Do pisma ideograficznego w sposób naturalny odnosi się metoda globalna, oparta na rozpoznawaniu znaków graficznych jako pewnych całości. Pismem obrazkowym było hieroglificzne pismo chińskie. Obecnie ma ono charakter ideograficzno-fonetyczny, a naukę czytania wspomaga transkrypcja fonetyczna. Pod koniec lat 50. XX wieku do szkół chińskich została wprowadzona alfabetyczna wersja języka chińskiego (Hanyu Pynyin). Teksty napisane językiem potocznym czyta się od lewej do prawej strony, językiem literackim natomiast - z góry na dół lub od prawej do lewej strony. W piśmie sylabicznym znaki graficzne - sylabogramy - symbolizują całe sylaby. Sylabariusz etiopski składa się ze 182 znaków typu CV (consonant-vowel syllable), z których każdy oznacza inną kombinację jednej z 26 spółgłosek z jedną z siedmiu samogłosek. Pismo japońskie jest systemem mieszanym sylabiczno-ideograficznym. Obok znaków kanji (znaków logograficznych pochodzenia chińskiego) występują znaki dwóch sylabariuszy ( $h i-$ ragana i katakana) (Polański 2003). Przy nauce czytania jako podstawową jednostkę metodyczną przyjmuje się sylabę. W piśmie alfabetycznym znaki graficzne (litery) odnoszą się do pojedynczych głosek (fonemów). Na dobór metody największy wpływ ma charakter zależności między fonemem a grafemem. Jeśli zależności te są w miarę regularne (jak w wypadku języka polskiego czy fińskiego), preferowane są metody analityczno-syntetyczne. W innej sytuacji pierwszeństwo przyznaje się metodom globalnym (jak np. w językach angielskim czy francuskim).

W okresie początkowej nauki czytania oraz doskonalenia tej umiejętności metodycy edukacji wczesnoszkolnej wyróżniają trzy etapy: przygotowawczy (rozwijanie podstawowych dla czytania i pisania funkcji psychofizycznych), elementarzowy (wprowadzanie liter) i poelementarzowy (automatyzacja techniki czytania i pisania) (Czelakowska 2013). W okresie elementarzowym dzieci opanowują sprawność mowy, czytania i pisania, rozwijają słownictwo i myślenie. Większość koncepcji nabywania umiejętności czytania pisania zaleca, aby umiejętności te rozwijać równolegle. Wybór odpowiedniego dla grupy i środowiska elementarza znacznie ułatwia ich przyswajanie. 


\section{Koncepcje i metody nauczania czytania i pisania}

Jak już wspominano, istnieją zróżnicowane podejścia wobec edukacji czytelniczej dziecka. W procesie dydaktycznym możemy mieć do czynienia z tzw. tradycyjnym typem edukacji czytelniczej - modelem fonologicznym (code oriented approach). Drugi model zakłada przetwarzanie informacji przez czytelnika w kontekście tworzonych przez niego przypuszczeń dotyczących znaczenia, jakie niesie za sobą czytany tekst - model "góra-dół” (top-down), implikując model holistyczny (integrated approach) odpowiedni dla dzieci młodszych. W trzecim z modeli - nazywanym interakcyjnym - zakłada się współwystępowanie obydwóch procesów w trakcie recepcji tekstu - „dół-góra” i „góra-dół”. Takie stanowisko określane jest w nauczaniu jako zrównoważone (balance approach) (Jaszczyszyn 2010). Istota modelu tradycyjnego tkwi w koncentracji na systemie językowym. Wyraźnie wyjaśniane jest istnienie związku między grafemem a fonemem. Praca opiera się na dokładnie opracowanych treściach programowych i elementarzu skoncentrowanym na fonograficznym aspekcie języka pisanego, cechuje ją silne umetodycznienie. W elementarzu wszystko podporządkowane jest sekwencyjnemu opanowywaniu umiejętności, które warunkują czytanie. Do umiejętności, jakie trzeba opanować, należą: rozpoznawanie liter, przyporządkowywanie poszczególnym literom głosek, stosowanie zasad fonetyki, dzielenie wyrazów na sylaby, określenie sensu wyrazu na podstawie kontekstu, określenie sensu wyrazu na podstawie słowotwórstwa, wyławianie zdań, zadawanie pytań odnoszących się bezpośrednio do tekstu i odpowiadanie na nie, zadawanie pytań problemowych odnośnie tekstu i odpowiadanie na nie. Zwolennicy podejścia fonetycznego argumentują, że aby nauczyć się czytać, większość dzieci potrzebuje sprecyzowanego nauczania reguł, jakimi podporządkowany jest tekst drukowany. Zalecana organizacja pracy z dziećmi polega na rozpoczynaniu przetwarzania informacji zawartych w tekście „od dołu”, czyli od rozpoznawania poszczególnych liter i przechodzenia na wyższe poziomy opracowywania informacji zawartych w tekście. Konsekwencją przyjętej w Polsce w latach 70. XX wieku instytucjonalnej organizacji edukacji czytelniczej, rekomendowanej do realizacji z dziećmi sześcioletnimi, był tradycyjny sposób pracy nauczycieli (Jaszczyszyn 2010, s. 46). W modelu tym wiodącą była metoda analityczno-syntetyczna o charakterze funkcjonalnym Ewy i Feliksa Przyłubskich. Taki model edukacji czytelniczej - skonkretyzowany w elementarzu Litery - oparto na założeniach cechujących model fonologiczny. Autorzy się starali, aby sposób jego realizacji był jak najbardziej przyjazny sześciolatkom, dlatego wprowadzili elementy metody globalnej, barwno-dźwiękowej. Ponadto zastosowali sylabę jako segment pośredni między głoską a wyrazem. Metody te określamy mianem eklektycznych, wykorzystuje się w nich bowiem elementy innych metod, łączy się różne podejścia. Starannie zaaranżowane, z odpowiednio przygotowanym materiałem do ćwiczeń, urozmaicają proces nauki czytania (Jurek 2012, s. 167). 
Ze względu na sposoby przeprowadzania operacji umysłowych można wyróżnić metody: syntetyczne (indukcyjne), analityczne (dedukcyjne), mieszane: syntetyczno-analityczne lub analityczno-syntetyczne, stopniowane (stopniowe budowanie słów), globalne (całościowe, leksykalne), eksperymentalne (wprowadzające innowacje poznawcze), eklektyczne (kombinowane). Wymienione metody mogą występować w różnych wariantach i odmianach. W zależności od tego, który kanał odbioru informacji jest angażowany jako pierwszy w procesie nauki, można wyróżnić następujące warianty metod czytania: foniczne (dźwiękowe), np. modelowanie struktury dźwiękowej słów D. B. Elkonina, wizualne (graficzne; wzrokowe), np. metoda zastosowana przez M. Falskiego, somaestetyczne (dotykowo-kinestetyczne), np. system Braille’a, polisensoryczne (wielozmysłowe), np. Metoda Dobrego Startu M. Bogdanowicz. W zależności od jednostki, która stanowi punkt wyjścia do nauki, metody czytania mogą występować w następujących odmianach: literowej (alfabetycznej/grafemowej) lub fonicznej (fonemowej), sylabowej (zgłoskowej), wyrazowej, związków wyrazowych, zdaniowej.

W metodzie Lesen durch Schreiben J. Reichena podstawą nauki czytania jest opanowanie przez dzieci umiejętności segmentowania słów na głoski, określania ich kolejności oraz scalania ich w wyrazy, a następnie zapis ich przy wykorzystaniu specjalnej tabeli nagłoskowej (Anlauttabele). Tabela zawiera ułożone w podkowę obrazki, przedstawiające obiekty (rysunki zwierząt, ludzi, przedmiotów) i przyporządkowane do nich litery lub połączenia liter symbolizujące głoski nagłosowe nazw tych obiektów. Dziecko wybiera z tabeli odpowiadające kolejnym głoskom litery i dokonuje zapisu danego wyrazu. Częste posługiwanie się tabelą i samodzielne zapisywanie przez dzieci słów automatycznie umożliwia im opanowanie czytania. Metoda ta nie uwzględnia jednak kaligrafii (Wieszczeczyńska 2007).

Szczegółowe analizy metod nauki czytania i pisania stosowane w polskich elementarzach z początku XXI wieku pozwalają ocenić skuteczność metod zdiagnozować, a następnie porównać poziom umiejętności uczniów kształconych zgodnie z daną koncepcją. Przykładem naukowej analizy wartości edukacyjnych najpopularniejszych metod alfabetyzacji w Polsce jest opracowanie wrocławskiej pedagog Anny Jurek. Niestety wnioski nie były optymistyczne, albowiem żaden z analizowanych pakietów nie zapewniał uczniom uzyskania optymalnych wyników w opanowaniu umiejętności posługiwania sie językiem pisanym i co gorsze nie umożliwiał osiągnięcia podstawowych umiejętności wymaganych na tym etapie edukacyjnym (Jurek 2012, s. 195).

\section{Nauka czytania i pisania w najpopularniejszym polskim elementarzu XX wieku}

Najsławniejszym polskim podręcznikiem jest z pewnością Elementarz Mariana Falskiego, który był najdłużej używanym w szkołach (aktualizowany i dostosowywany do ówczesnej rzeczywistości), niemal do końca XX wieku. Z kolejnych 
jego wydań uczyło się kilka pokoleń Polaków w kraju i na świecie. Po raz pierwszy elementarz ukazał się w roku 1910 w Krakowie pt. Nauka czytania i pisania dla dzieci. Dwa ostatnie jego wydania znajdują się w stałej sprzedaży (i użyciu), tj. reprint z 1971 roku i wydanie z pięknymi ilustracjami Janusza Grabiańskiego. Fenomen Elemantarza Mariana Falskiego tkwi w bardzo starannie przemyślanej, opartej na podstawach naukowych koncepcji wczesnoszkolnej edukacji językowej. Autor starannie dobierał materiał językowy do ćwiczeń, uwydatnił m.in. znaczenie kaligrafii w opanowaniu ortografii, zastosował metodę analityczno-syntetyczną o odmianie wyrazowej, z zachowaniem zasady stopniowania trudności. Podstawę elementarza stanowiły zasady początkowej nauki czytania, zgodnie z którymi: „1. Rozpoczynanie nauczania od wyrazów i zdań prostych, nie od liter. 2. Poznawanie liter i zgłosek powinno być produktem analizy wyrazów. 3. Tekst do czytania powinien się składać ze znanych dziecku słów. 4. Wyrazy powinny być przeważnie jednosylabowe. 5. Przy nauczaniu czytania trzeba posługiwać się rysunkiem. 6. Nauczanie należy zaczynać od tekstu pisanego, nie drukowanego" (Wroczyński 1988; Jakubowicz-Bryx 2010). W kolejnych wydaniach autor wprowadził wzajemne powiązanie czytania z pisaniem poprzez poznawanie zarówno małych i wielkich znaków drukowanych, jak i małych i wielkich pisanych, tak aby utrzymać zasadę równoległości postępów dziecka w nabywaniu umiejętności czytania z jednoczesną nauką pisania. Ponadto twórca elementarnej nauki czytania i pisania w swej koncepcji akcentował znaczenie kształcenia językowego w połączeniu z ortograficznym, od początku konsekwentnie stosował znaki interpunkcyjne, ćwiczenia w przekształcaniu wyrazów, jako skuteczny sposób pogłębiania umiejętności świadomej syntezy, ćwiczenia morfologiczne (słowotwórcze i fleksyjne), pozwalające zrozumieć budowę wyrazów i reguły ich odmiany. Elementarz z 1971 roku i wydania późniejsze otwiera osiem całostronicowych ilustracji, które miały służyć do ćwiczeń w mówieniu, przygotowujących do nauki czytania, na kolejnych stronach zamieszczone są teksty fabularne, których treść była bliska dziecku. Słuszność zaleceń Falskiego potwierdziły badania porównawcze nad elementarzami. Podobny układ zachowują współczesne polskie elementarze.

\section{Bukwar - rosyjski elementarz Daniela Borysowicza Elkonina}

Daniel Borysowicz Elkonin, wybitny rosyjski psycholog dziecięcy, zastosował i upowszechnił w Bukwarze (elementarzu wykorzystywanym w Rosji) metodę modelowania dźwiękowej struktury słów. Autor wykorzystał w niej teorię kształtowania działań umysłowych A. N. Leontjewa i P. J. Galpierina, opartą na koncepcji strefy najbliższego rozwoju (zone of proximal development) Lwa Siemionowicza Wygotskiego. W Rosji za jedną z najważniejszych prac Elkonina uważa się Jak nauczyć dzieci czytania (Как научить детей читать) z 1976 roku $^{6}$, zaś eksperymentalny

6 Przetłumaczona na język polski przez Annę Jurek w roku 2015. 
dwuczęściowy elementarz Bukwar (Букварь экспериментальный, cz. 1, wydana w 1969 roku i Букварь экспериментальный, cz. 2, wydana w 1972 roku) nadal jest wznawiany. Część pierwsza przeznaczona jest do przygotowania dzieci do nauki czytania. Najpierw są one zapoznawane z budową sylabową wypowiadanych słów, głównie w celu określenia miejsca ich akcentu, który w języku rosyjskim jest ruchomy. Następnie uczniowie poznają fonemy samogłoskowe i uczą się odróżniać je od fonemów spółgłoskowych. Po opanowaniu podstawowej wiedzy o funkcjonowaniu systemu fonologicznego rozpoczynają ćwiczenia w rozpoznawaniu pierwszego dźwięku w słowach i przeprowadzaniu analizy oraz syntezy fonemowej nazw przedstawionych na elementarzowych obrazkach. Na kolejnym etapie uczniowie uczą się rozpoznawać fonemy twarde i miękkie. Pomocą w tym służą im specjalne oznaczenia graficzne. Zgodnie z nimi dzieci przeprowadzają analizę fonemową słów. Po poznaniu systemu dźwięków języka rosyjskiego i składu fonemowego słów rozpoczyna sie etap zaznajamiania dzieci z literami samogłoskowymi, a następnie spółgłoskowymi. Uczniowie się dowiadują, jak „pracują” wszystkie litery. Autor bowiem personifikował pojęcia językowe (litery mieszkają, pracują, błądzą, a słowa bywają sprytne lub chytre). Litery samogłoskowe służące do oznaczania twardości i miękkości fonemów spółgłoskowych wprowadzane są parami. Ważne miejsce zajmują ćwiczenia fonologiczne. Po etapie ćwiczeń w tworzeniu modeli słów następuje faza ćwiczeń w transformowaniu fonemów w słowach (w Elementarzu Elkonina znajdziemy wiele ćwiczeń pozwalających dzieciom uświadomić sobie, że zmiana głoski w danym słowie zmienia jego znaczenie, opozycje fonologiczne) i w dalszej kolejności faza polegająca na przekształcaniu podanego modelu graficznego w inny schemat. Każda $\mathrm{z}$ tych faz powinna stopniowo doprowadzić uczniów do wymawiania fonemów na głos, zdobycia umiejętności wykonywania ćwiczeń w mowie wewnętrznej. Zrozumienie przez dzieci faktu, iż słowa składają się z pojedynczych dźwięków, które można zapisać za pomocą liter, stanowi przełomowy moment $\mathrm{w}$ zdobyciu przez nie umiejętności posługiwania sie językiem pisanym. Jednocześnie z ćwiczeniami w czytaniu i pisaniu wprowadzane są ćwiczenia rozwijające sprawności językowe.

\section{Współczesne elementarze niemieckie - wybór}

W Niemczech rynek podręczników szkolnych jest rozproszony. Nauczyciele wybierają podręczniki do pracy w klasie $\mathrm{z}$ listy książek zatwierdzonych $\mathrm{w}$ danym landzie (Tainio, Winkler 2014). Podręczniki te spełniają założenia, realizują cele i treści przedstawione w narodowym dokumencie German Bildungsstandards (KMK 2004), który jest odpowiednikiem polskiej podstawy programowej. Dla etapu początkowego w różnych wydawnictwach opracowano elementarze wraz $\mathrm{z}$ bogatą, różnorodną obudową metodyczną.

Germanistka Ewa Wieszczeczyńska (2007) w swym studium porównawczym analizuje szczegółowo trzy elementarze wydane po roku 2000: Mobile 1 - lesen 
und schreiben, $A B C$ Reise, Meine Fibel. Dziś mają one już nowsze wersje lub nie są wznawiane $A B C$ Reise, ale koncepcja nauki czytania i pisania nie zmieniła się radykalnie. Wydawnictwa w nowej ofercie odpowiadają przede wszystkim na indywidualne potrzeby dzieci, które uczą się w heterogenicznych zespołach klasowych. Pierwszy z elementarzy Mobile 1 - lesen und schreiben, autorstwa I. Dudek, M. Elbert, C. Schenk, z 2000 roku (ostatnie wydanie w 2010 roku) ${ }^{7}$ bazował na metodzie zintegrowanej, będącej połączeniem metody analityczno-syntetycznej i globalnej, a dodatkowym jej uzupełnieniem był alfabet demonstracyjny. Naukę czytania i pisania rozpoczynała się od wprowadzenia w pierwszym rozdziale elementarza alfabetu demonstracyjnego w kształcie tęczy, za pomocą którego dzieci samodzielnie zapoznawały się z obrazem graficznym i fonicznym poszczególnych liter i połączeń literowych. Zastosowanie alfabetu stwarzało na początku nauki czytania i pisania możliwość samodzielnego zapisywania wyrazów i zdań - jest to etap tzw. zapisu fonetycznego (dzieci zapisują tak, jak słyszą). Umożliwia on zrozumienie zasady funkcjonowania pisma alfabetycznego (zależności między głoską a literą). Na dalszych etapach nauki uczniowie poznawali poszczególne litery i połączenia literowe na drodze analizy i syntezy oraz wybrane wyrazy w sposób globalny. Dzięki zastosowaniu metody zintegrowanej od samego początku w elementarzu pojawiały się ciekawe teksty. Wprowadzenie nowej litery odbywało się poprzez analizę wzrokową wyrazów podstawowych, które były wyodrębniane z zapisanego na tablicy zdania. Nauczyciel podkreślał wyrazy, w których znajdowała się nowo wprowadzana litera. Uczniowie próbowali odgadnąć, którą literę będą poznawać bliżej. Następnie nauczyciel zawieszał na tablicy literę z alfabetu demonstracyjnego wraz z obrazkiem, w którego nazwie poznawana głoska była w nagłosie i odpowiadała poznawanej literze. Dalsze fazy wprowadzania litery i głoski obejmowały ćwiczenia z zakresu analizy słuchowej, artykulacji, analizy wzrokowej oraz aktywizacji zmysłów. Proces nauki czytania i pisania oparty był na aktywizacji jak największej ilości zmysłów, służyły więc temu różnorodne ćwiczenia w zakresie kształtowania słuchu fonematycznego, odkrywaniu zależności między literą i głoską na bazie alfabetu demonstracyjnego, ćwiczenia artykulacyjne, ćwiczenia ruchowe polegające na układaniu wzoru liter z różnych materiałów, grafomotoryczne z wykorzystaniem różnych powierzchni.

Elementarze z serii Jo-Jo (2012), Piri (2010), Meine Fibel (2009), Tinto (2008), Karibu (http://www. cornelsen. de 2016; http://verlage.westermanngruppe.de) to obecnie dość popularne serie podręczników do nauki języka niemieckiego dla dzieci. Warto zwrócić uwagę na pierwszy z nich: Jo-Jo Fibel, którego autorką jest Nicole Namour. Narratorami i zarazem pierwszymi czytelnikami elementarza są

7 Kolejne wersje podręczników dla dzieci z serii Mobile 1 - Allgemeine Ausgabe, 2010 - ukazały się pod redakcją Claudii Crämer i Kathriny Walcher-Frank w wydawnictwie Westermann, dostępny na: http://flashbook.westermann.de/mobile1-lesebuch-978-3-14-124340-6 (otwarto: 31.07.2016). 
Nina, Nino i ich pies Jojo (Grundschule Mit Beenen Lehrmittel, 2016). Elementarz zawiera zintegrowane podejście do nauki czytania. Dominuje w nim metoda analityczno-syntetyczna; sylaba jest elementem pośrednim (sylaby są wyróżnione kolorem zielonym w tekstach). Podręcznik posiada przejrzyście skonstruowane strony, współczesne ilustracje, zawiera propozycje różnicowanych, zorientowanych na działanie zadań do pracy, teksty z fragmentami literatury dziecięcej (np. Pipi Långstrump Astrid Lingren, gry językowe i teksty autentyczne - użytkowe, np. listy i pocztówki z wakacji).

Koncepcja dydaktyczna zróżnicowania (Differenzierungskonzept) jest istotna we współczesnych elementarzach niemieckich. Seria podręczników Tinto została skonstruowana wokół podejścia otwartego - uwzględnia zróżnicowany poziom umiejętności i możliwości uczniów. Na początku elementarza znajduje sie tzw. dom liter (Buchstabenhaus). Podręcznikom Meine Fibel przyświeca hasło: uczymy się razem - choć różnie (Gemeinsam lernen - aber differenziert). Podręcznik reprezentuje szerokie podejście do procesu czytania - równolegle kształci się zarówno techniczną stronę tego procesu, jak i rozumienie czytanych tekstów. Nauka czytania i pisania odbywa się zgodnie z metodą analityczno-syntetyczną. Wprowadzenie nowej litery i głoski ma miejsce poprzez wyodrębnienie jej z pewnej całości językowej. W trakcie rozmowy na temat obrazka lub jego fragmentu, bądź też podpisu pod ilustracją, tytułu czy własnych przeżyć uczniów, związanych np. z określonym zdarzeniem na lekcji, zostają wyodrębnione wyrazy podstawowe, przewidziane do analizy wzrokowej. Następnie nauczyciel zaznacza nową literę i czyta wyrazy na głos lub/i uczniowie odczytują nowe wyrazy z pomocą alfabetu demonstracyjnego. W dalszych etapach wprowadzania nowej litery przeprowadza się ćwiczenia w zakresie analizy i syntezy (słuchowej i wzrokowej).

W podręczniku zamieszczone są fragmenty współczesnych tekstów z dziecięcej literatury klasycznej i współczesnej, np. bajka Trzy Świnki czy krótka informacja o szwedzkim autorze (Sven Nordqvist) i fragment tekstu z niezwykle popularnej serii o Pettsonie i kocie Findusie. W większości współczesnych niemieckich elementarzy na pierwszych stronach zamieszcza się alfabet demonstracyjny. Przybiera on kształt domku, tęczy, statku kosmicznego. Na pierwszych stronach (ilustracjach) zawsze w zespole klasowym pojawia się dziecko niepełnosprawne (siedzące na wózku) lub ciemnoskóre. Tematem podejmowanym w ramach wczesnoszkolnej edukacji językowej jest kultura dnia codziennego, a sytuacją opisywaną dziecięcy świat, np. ja i moja rodzina/przyjaciele, przedszkole/szkoła, gry i zabawy, hobby, sport, zwierzęta, podróże, pory roku/pogoda, jedzenie i picie, ciało/zdrowie, ubranie, święta i zwyczaje, ochrona środowiska, ale także poznawanie dnia powszedniego/zwyczajów także dzieci z innych krajów. 


\section{Zakończenie}

Podręczniki odzwierciedlają kulturę edukacyjną danego kraju, są źródłem reguł, norm i wzorców zachowań podzielanych przez dorosłych, którzy w nie wierzą i pragną zaszczepić je młodszym pokoleniom (Falk, Pingel 2010). Kształt i formuła elementarzy na przestrzeni dziejów jest nierozerwalnie związana $z$ ideami danej epoki, aktualną myślą pedagogiczną, a także rozwojem sztuki edytorskiej, dlatego elementarze różnią się od siebie doborem materiału językowego (wyrazów i tekstów „czytanek”), szatą graficzną oraz rozwiązaniami metodycznymi uznanymi za odpowiednie dla danego systemu językowego. Przed wiekami abecadlniki i elementarze były pierwszymi książkami intencjonalnie wprowadzającymi dzieci w świat pisma ${ }^{8}$. Dla wielu dorosłych elementarz pozostaje miłym wspomnieniem szczęśliwych, beztroskich lat dzieciństwa. W czasach współczesnych, kiedy pierwsze książki oferuje się matce chwilę po narodzinach dziecka, a w przedszkolach wprowadza się elementarze dla trzylatka, czterolatka, elementarz nie jest już ani jedyną pomocą dydaktyczną, ani też podstawowym narzędziem alfabetyzacji kulturowej i ikonograficznej (Konarzewski 2006; Konarzewski, Bulkowski 2017). Funkcje inicjacyjne - wprowadzania w świat pisma - elementarz spełnia niezmiennie w krajach o bardzo niskim współczynniku alfabetyzacji. Z całą pewnością dobrze przemyślana pierwsza książka do czytania nadal może pełnić rolę efektywnego środka dydaktycznego, tym bardziej że autorom nie brak inwencji twórczej i ciągle podejmują próby stworzenia idealnego elementarza. Nie należy zapominać, że elementarze są z powodzeniem wykorzystywane w nauczaniu dzieci języków obcych. Elementarz pozostaje podstawowym materiałem dydaktycznym do wczesnej nauki czytania i pisania w Polsce (Awramiuk i in. 2017). Najnowsze elementarze polskie wyraźnie nawiązują do Elementarza Mariana Falskiego (Zabawa, 2015). W Elementarzu współczesnym Anny Bobryk ${ }^{9}$ i Doroty Nowackiej, wydanym w 2015 roku przez wydawnictwo Egmont, zastosowana została metoda analityczno-syntetyczna - tradycyjnie stosowana w polskich elementarzach od czasów Konrada Prószyńskiego, Beata Ostrowicka natomiast, autorka Poczytam ci, mamo. Elementarz, pozycji wydanej przez Naszą Księgarnię, postawiła na promowaną współcześnie na świecie metodę globalną. Innowacyjną koncepcję pracy ze znakomicie zilustrowanymi tekstami literackimi przygotowała Małgorzata Swędrowska (2017), autorka Elementarza w podskokach, opartego na koncepcji czytania wrażeniowego. To sposób inicjowania spotkań czytelniczych łączących przeżycie tekstu literackiego z ruchem, rytmem, rymem i emocjami, np. integracyjne tańce i inne formy aktywności fizycznej. Zmiana ilości dostępnych na polskim

8 Erudycyjne i zarazem bardzo zwięzłe studium poświęcone dziejom elementarzy na świecie i w Polsce opracowała Elżbieta Zarych w internetowej Encyklopedii Dzieciństwa.

9 Anna Bobryk zdobyła Złotą Nagrodę Best European Schoolbook Award na prestiżowych Targach Książki we Frankfurcie za pakiet do klas 1-3 pt. Tropiciele (2013), dla najlepszego cyklu edukacyjnego w Europie w kategorii wiekowej 6-9 lat. 
rynku materiałów edukacyjnych nie miała wpływu na dokonanie redefinicji roli elementarza. W dalszym ciągu pozostaje on bardzo istotnym elementem procesu dydaktycznego, a o wyborze odpowiedniego podręcznika decyduje nauczyciel bądź zespół nauczycieli.

W tradycji anglosaskiej rola elementarzy jest inna niż w Polsce. Nauczyciel ma większa autonomię $\mathrm{w}$ wyborze elementarza $\mathrm{z}$ bogatej oferty rynkowej, częściej przygotowuje lekcje samodzielnie; są one zindywidualizowane, zgodnie z potrzebami uczniów, a materiały do nauki dobiera w konsultacji z innymi nauczycielami. Podobna sytuacja ma miejsce w Polsce, bowiem z każdym rokiem wzrasta świadomość nauczycieli w zakresie organizowania środowiska sprzyjającego uczeniu się dziecka, wzrasta także niezależność nauczycieli w decydowaniu o wyborze odpowiednich dla konkretnego dziecka materiałów do nauki czytania i pisania.

\section{Bibliografia}

Arlette D., De Coster I., Baidak N., Motiejunaite A., Noorani S., (red.). (2011). Nauka czytania w Europie. Warszawa: Fundacja Rozwoju Systemu Edukacji.

Awramiuk E. (2006). Lingwistyczne podstawy początkowej nauki czytania i pisania po polsku. Białystok: Trans Humana Wydawnictwo Uniwersyteckie.

Awramiuk E., Krasowicz-Kupis G. (2014). Reading and spelling acquisition in Polish: Educational and linguistic determinants. „L1-Educational Studies in Language and Literature", 14, s. 1-24.

Awramiuk E., Krasowicz-Kupis G., Smoczyńska M. (2017). Early literacy policy and practice in Poland. W: Kucirkova N., Snow C. E., Grøver V., McBride C. (red.). The Routledge International Handbook of Early Literacy Education A Contemporary Guide to Literacy Teaching and Interventions in a Global Context, London \& New York: Routledge.

Brzezińska A. (red.). (1987). Czytanie i pisanie - nowy język dziecka. Warszawa: Wydawnictwa Szkolne i Pedagogiczne.

Cackowska M. (1984). W poszukiwaniu koncepcji optymalnego elementarza. Lublin: UMCS.

Coulmans F. (1999). The Blackwell Encyclopedia of Writing Systems. Oxford: Wiley-Blackwell.

Czelakowska D. (2009). Znaczenie elementarza w procesie nauki czytania i pisania. W: Metodyka edukacji polonistycznej dzieci w wieku wczesnoszkolnym. Kraków: „Impuls”.

Elkonin D. (2015). Jak uczyć dzieci czytania. Wrocław: Oficyna Wydawnicza Atut Wrocławskie Wydawnictwo Oświatowe.

Encyklopedia językoznawstwa ogólnego (2003). Polański K. (red.). Wrocław: Zakład Narodowy im. Ossolińskich.

Falk P. (2010). UNESCO Guidebook on Textbook Research and Textbook Revision. and revised and updated edition, Paris: Braunschweig. 
Frith U. (1985). Beneath the surface of developmental dyslexia. W: Patterson K., Coltheart M., Marshall J. (red). Surface Dyslexia. Londyn: LEA.

Grundschule Mit Beenen Lehrmitteln. Katalog. (2016). Cornelsen (e-book), dostępny na: http://www.cornelsen.de/lehrkraefte/reihe/r-2929/ra-10629/titel?back_ link=search (otwarto: 31.07.2016).

Jakubowicz-Bryx A. (2010). Historia pewnego elementarza. „Życie Szkoły”, nr 7, s. $26-36$.

Jaszczyszyn E. (2010). Modele edukacji czytelniczej w przedszkolu a gotowość do czytania i umiejętności czytania dzieci sześcioletnich. Białystok: Trans Humana. Wydawnictwo Uniwersyteckie.

Jurek A. (2012). Rozwój dziecka a metody nauczania czytania i pisania. Gdańsk: Harmonia Universalis.

Klus-Stańska D. (2014). „Nasz elementarz” - krótki opis daru, który zubaża obdarowanych. „Problemy Wczesnej Edukacji”, nr 4, s. 24-44.

Konarzewski K. (2007). PIRLS 2006. Jak czytają dzieci w Polsce i na świecie. Warszawa: CKE.

Konarzewski K., Bulkowski K. (2017). Wyniki międzynarodowego badania osiągnięć czwartoklasistów w czytaniu. PIRLS 2016. Warszawa: IBE.

Kostouli T. (2002). Teaching Greek as l1: curriculum and textbooks in Greek elementary education. „L1 - Educational Studies in Language and Literature”, nr 2, s. 5-23.

Krasowicz-Kupis G. (1999). Rozwój metajęzykowy a osiągnięcia w czytaniu u dzieci 6-9-letnich. Lublin: Wydawnictwo Uniwersytetu Marii Curie-Skłodowskiej.

Krasowicz-Kupis G. (2008). Psychologia dysleksji. Warszawa: WN PWN.

Krzyżyk D. (2015). Odzwierciedlenie funkcji podręcznika w języku i stylu. W: Opinie edukacyjne Polskiej Akademii Umiejętności. Prace Komisji PAU do oceny podręczników szkolnych. T. XIII. Kraków: Wydawnictwo PAU, s. 61-81.

Landau-Czajka A. (2002). Diet patterns in 19th-2oth c. School manuals. „Acta Poloniae Historica", 85.

Machcińska M. (2015). Abecadlniki karaimskie. „Kwartalnik Historii Żydów”, 4 (256), s. 691-697.

Malmquist E. (1982). Nauka czytania w szkole podstawowej. Warszawa: Wydawnictwa Szkolne i Pedagogiczne.

Reading the past, writing the future: Fifty years of promoting literacy. (2017). Paryż: UNESCO. Education Sector.

Seymour P H.K., Aro M., Erskine J., (2003). Foundation literacy acquisition in European orthographies. „British Journal of Psychology”, 94 (2), s. 143.

Seymour P. (1999). Cognitive architecture of early reading. W: Lundberg I., Toennessen F. E., Austad I. (red.). Dyslexia: Advances in theory and practice. Dordrecht: Kluwer Academic Publishers, s. 59-73.

Sochacka K. (2004). Rozwój umiejętności czytania. Białystok: „Trans Humana”. 
Swędrowska M. (2017). Elementarz w podskokach. Poznań: Centrum Edukacji Dziecięcej - Publicat.

Szefler E. (2017). Nietypowy (międzynarodowy) elementarz. „Problemy OpiekuńczoWychowawcze", nr 2, s. 53-60.

Szewczuk K. (2015). Language Education of Children at the Early Schooling Age in the Aspect of Handbooks Used. „Edukacja Elementarna w Teorii i Praktyce”, 4 (38), s. 71-90.

Tainio L., Winkler I. (2014). The construction of ideal reader in German and Finnish textbooks for literacy education. „L1-Educational Studies in Language and Literature", vol. 14, s. 1-25, dostępny na: http://dx.doi.org/10.17239/L1ESLL (otwarto: 1.05.2014).

Uszyńska-Jarmoc J., Żak M. (2013). The first schoolbook - the tool of reproducing culture by the child or the tool of child's participation in culture? „L1-Educational Studies in Language and Literature", vol. 13, s. 1-18.

Wiejak K., Krasowicz-Kupis G., Awramiuk E. (2017). Językowe uwarunkowania wczesnych umiejętności czytania i pisania na podstawie oceny nauczyciela $z$ wykorzystaniem skali prognoz edukacyjnych IBE. „Psychologia Wychowawcza”, nr 11, s. 41-63.

Wieszczeczyńska E. (2007). Wczesnoszkolna edukacja językowa a nauczanie czytania. Program alfabetyzacji w języku niemieckim jako obcym na przykładzie wybranych metod i elementarzy. Wrocław: Oficyna Wydawnicza ATUT, Wrocławskie Wydawnictwo Oświatowe.

Wiśniewska-Kin M. (2013). Dominacja a wyzwolenie: wczesnoszkolny dyskurs podręcznikowy i dziecięcy. Łódź: Wydawnictwo Uniwersytetu Łódzkiego.

Wroczyński R. (1988). Marian Falski i reformy szkolne w Rzeczypospolitej. Warszawa: PWN.

Zabawa K. (2015). Elementarze XXI wieku. „Edukacja Elementarna w Teorii i Praktyce", nr 4, s. 153-158.

Zarych E. Elementarze. W: Encyklopedia Dzieciństwa, dostępny na: http://encyklopediadziecinstwa.pl/index.php?title=Elementarz (otwarto: 30.03.2018).

http://www.cornelsen.de/lehrkraefte/reihe/r-5247/ra- 10175/titel/9783060835140/ back_link/search (otwarto: 31.07.2016).

https://verlage.westermanngruppe.de/westermann/artikel/978-3-14-121068-2/

Karibu-Ausgabe-2016-Fibel-fuer-die-Ausleihe (otwarto: 31.07.2016).

\section{SCHOOL LEARNING TO READ AND WRITE USING SELECTED TEXTBOOKS - METHODOLOGICAL REFLECTIONS}

\footnotetext{
Abstract: The text deals with learning to read and write at the initial stage of school education and the role of textbooks in the process of child literacy. The article is of a review
} 
nature. The first part shows the psycholinguistic basics of reading and writing and the differences between language systems, conditioning the use of specific methods of learning to read and write. The structure, function and methodical aspects of work with textbooks were described, which was treated as an effective didactic aid and effective form of the child's initiation into the world of writing. In the second part, selected textbooks and the concepts of reading and writing science proposed by their authors are characterized. The traditional approach - didactic and non-evaluative approach - was used to analyze the textbooks. Finally, examples of contemporary Polish, German and one Russian textbook are indicated. The criterion for their selection was the long-term use (nearly half a century) in the first years of school education and the dominance of analytical and synthetic methods in the teaching of reading and writing.

Keywords: early literacy, reading and writing, contemporary textbooks.

Marta Krasuska-Betiuk - doktor, starszy wykładowca w Instytucie Wspomagania Rozwoju Człowieka i Edukacji Akademii Pedagogiki Specjalnej im. M. Grzegorzewskiej w Warszawie. Autorka i współautorka publikacji: O poszukiwaniu, poznawaniu i tworzeniu samego siebie. Perspektywa teoretyczna i praktyczna (2016); Kreatywność jako wymiar profesjonalizacji przyszłych nauczycieli wczesnej edukacji (2017) oraz artykułów w czasopismach, m.in.: „Problemy Wczesnej Edukacji”, „Forum Oświatowe”, „Kultura i Edukacja”, „Studia z Teorii Wychowania”, „Kwartalnik Pedagogiczny”. Adres do korespondencji: ul. Szczęśliwicka 40; 02-353 Warszawa. Adres e-mailowy: mbkar@aps.edu.pl. 